\title{
Reproduction of Varroa jacobsoni in colonies of Apis cerana indica under natural and experimental conditions
}

\author{
NC Tewarson 1,2, A Singh 1, W Engels 2 \\ 1 Ewing Christian College, Department of Zoology, Allahabad 211003, India; \\ 2 Zoologisches Institut der Universität Tübingen, Auf der Morgenstelle 28, \\ D-7400 Tübingen, Germany
}

(Received 11 March 1991; accepted 11 February 1992)

\begin{abstract}
Summary - In North India the infestation with Varroa jacobsoni of drone and worker brood in Apis cerana colonies was checked monthly. Natural reproduction of the mite was found to be restricted to drone brood and to springtime. The potential reproduction in worker brood was investigated by artificially induced infection. Since the bees recognized and eliminated any mites originating from other hives, the grafting was performed within the same colony. Even then, $75 \%$ of the transferred mites were removed by the bees. Of the remaining Varroa females, about $90 \%$ were found to be infertile. The significance of the hitherto known varroatosis resistance factors related to reproduction is discussed with regard to a balanced host-parasite relationship.
\end{abstract}

Apis cerana indica / Varroa jacobsoni / reproduction / female mite infertility / varroatosis resistance

\section{INTRODUCTION}

The host-parasite relationships between the eastern honey bee, Apis cerana, and the mite, Varroa jacobsoni, has not been sufficiently studied. Several observations suggest that low reproduction of the parasite in worker brood plays an important role in varroatosis resistance of Apis cerana (Koeniger et al, 1981; Tewarson, 1987; de Jong, 1988). Female mite fertility was presumed to be regulated by the level of juvenile hormone present in the hemolymph of its host, particularly of late 5th instar bee larvae (Hänel and Koeniger,
1986). However, this could not be confirmed by a recent titer study using radioimmunoassay techniques (Rosenkranz et al, 1990). Comparable data on the hormone titer in Apis cerana larvae are lacking. Therefore the question of why Varroa reproduction succeeds only on drone brood in cerana bees remains open.

Since higher parasitization of drone brood in both the original host, Apis cerana (Koeniger et al, 1983; Tewarson, 1987; de Jong, 1988), and the secondary host, Apis mellifera (Sulimanovic et al, 1982; Engels et al, 1984; Issa and Gonçalves, 1984; Schulz, 1984; Rosenkranz and En- 
gels, 1985; Fuchs, 1990) is well documented, one possible explanation might be that, in the case of the eastern honey bee, reproductive mites avoid worker brood because of the low probability to survive. If introduced they could perhaps become fertile in this microhabitat.

In order to test this hypothesis, we transferred reproductive Varroa females between already capped drone and worker brood cells of Apis cerana. Because preliminary observations indicated that the bees easily recognize any alien mites, the transfer was carried out within the same colony. The reproductive success of such grafted mites was checked about a week later. The experiments were carried out in India during the early spring breeding season. At the same time the rate of natural brood infestation was checked.

\section{MATERIALS AND METHODS}

\section{Timing of the experiments within the annual colony cycle in North India}

At Allahabad, spring begins in late January. At this time, a rise in brood rearing can be observed in all Apis cerana indica colonies. Swarming occurs in March and April. Drones are usually present from February until midMay. In the hot month of June adult drones disappear in many colonies, and in July the brood nest becomes small. The monsoon rain begins at the end of June or the first half of July. During the monsoon season there is little nectar flow, and the colonies fade. Rain terminates in August, but forage is scarce until the end of September. In October and November during the fall blossom, the colonies are stimulated to breed again. In December, brood rearing is largely interrupted by the brief winter cold. Hence at Allahabad, brood is present throughout the year, and in strong colonies some drone larvae may be found at any time. The best period for experiments requiring abundant drone brood, however, is early springtime.

\section{Beekeeping at Allahabad}

Beekeepers multiply Apis cerana indica colonies by division and also try to catch swarms. There is no queen-rearing practised in the Allahabad region. Therefore, the local bee population consists of a mixture of hived and feral colonies. Many beekeepers have only 2 or 3 colonies, and large apiaries are found mainly in the mountain areas of Uttar Pradesh state. The average annual honey yield per colony is about 2.5-4.5 $\mathrm{kg}$. Varroatosis in the eastern honey bee does not require any control measures.

\section{Experimental colonies}

Experimental colonies of Apis cerana indica were maintained on the campus of Ewing Christian College, Allahabad. The wooden hives contained 8 brood frames measuring $28 \times 18 \mathrm{~cm}$ and a super $28 \times 9 \mathrm{~cm}$ with the same number of honey frames. For 2 naturally built brood combs the number of cells per square unit of each was determined. We counted $423-446$ cells per $100 \mathrm{~cm}^{2}$ for the drone combs and 660-693 for the worker combs.

For the experiments 10 strong colonies with a minimum of 5 covered brood combs and plenty of drone brood were selected. Only healthy colonies without sacbrood or other infections were used. To keep the colonies in good condition, syrup was given from July through September and again from mid-November through midJanuary. About $2 \mathrm{~kg}$ of sugar was fed per colony.

\section{Control of natural Varroa infestation}

Natural brood infestation by Varroa jacobsoni was checked throughout the year in the experimental colonies. Twice a month 100 sealed worker and, if available, the same number of drone brood cells per hive were opened and inspected for mites. In all colonies Varroa jacobsoni was present all times, but no visible hazard was recorded. Corresponding observations have been made since we began our varroatosis research project in 1984. 


\section{Artificial infection of worker broad}

The experiments were conducted from January through April in 1988 and 1989. Out of the 10 experimental hives, $1-3$ at a time were randomly used per transfer day, resulting in a total of 42 within-colony graftings at 24 dates (table 11 ). Individual brood cells were marked by means of a transparent sheet. For grafting, Varroa jacobsoni females were removed from recently capped drone cells. In a transfer experiment, 12-15 female mites were collected within 10-15 $\mathrm{min}$ and stored in a Petri dish on wet paper. Only supposedly reproductive mites with swollen opisthosoma were taken. A small opening in the capping of a freshly sealed worker brood cell was made with forceps. A mite was positioned at the end of a needle and introduced into the cell. The cell was then sealed again using a hot needle. This grafting was carried out within the same colony, because we had observed in preliminary experiments that the bees easily recognized and removed mites originating from other colonies, in particular if collected in Apis mellifera hives. Eight to 10 days later, the artificially infected cells were opened and inspected for a normally developed host pupa and the presence of a female mite and eggs. Over the 2 spring seasons, a total of more than 400 female mites were transferred.

\section{RESULTS}

\section{Natural colony infestation}

January through May, during the drone brood and swarming season, only very few worker cells were found to contain female mites. The maximum infestation constituting less than $1 \%$ was usually observed in March. At this time the ratio of parasitized worker and drone brood cells was approximately 1:30. However, during the rainy season, particularly from mid-June through mid-September, a number of Varroa females were found to have invaded the worker brood. Then the brood nest was reduced to 1 or 2 combs, and little or no drone brood was available. In some colo- nies $6-8 \%$ of the sealed worker cells were infested. One and occasionally even 2 female mites were present. All these Varroa females were apparently infertile, since no eggs or nymphs were detected in worker cells.

During the experiments, which lasted from January through April, the rate of drone brood infestation varied considerably among the 10 hives and over the course of the season (table I). The range was from $0-54.0 \%$ in 1988 and from 1.5$60.5 \%$ in 1989 . The monthly mean percentage of infested drone brood celis was between 5.1 and $34.0 \%$ (fig 1). In 1988 the peak of drone brood parasitization was reached in March; and in 1989 already by February, but which continued in March. In 1989 the level of infestation was higher than in 1988. Similar fluctuations had been recorded in previous years. In the spring periods, practically all female mites in

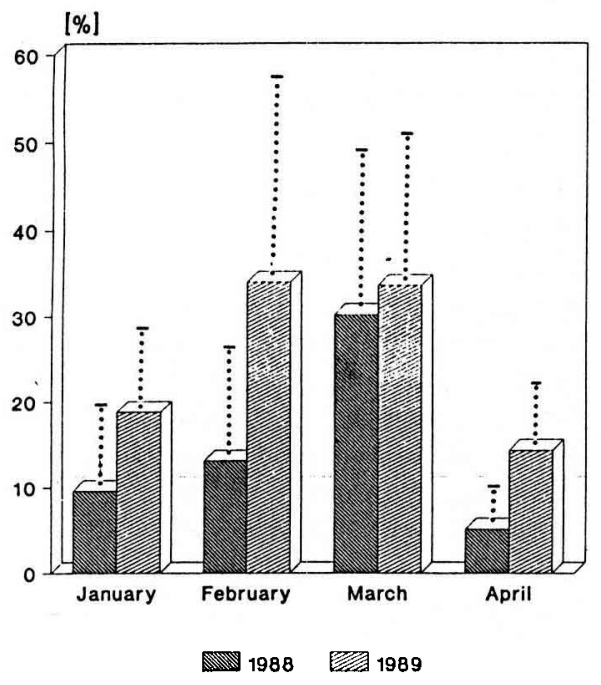

Fig 1. Incidence of natural drone brood infestation by Varroa jacobsoni during springtime in 10 colonies of Apis cerana indica. Overall means of two inspections of 100 capped cells per month and colony. Bars indicate standard deviation. 
Table I. Percentages of natural infestation of drone brood by Varroa jacobsoni during springtime in colonies of Apis cerana indica. Twice per month 100 sealed cells per colony were checked. Bold type indicates minimum and maximum rates of parasitized brood cells in individual colonies for both years.

\begin{tabular}{|c|c|c|c|c|c|c|c|c|c|c|}
\hline Colony No & 1 & 2 & 3 & 4 & 5 & 6 & 7 & 8 & 9 & 10 \\
\hline \multicolumn{11}{|l|}{1988} \\
\hline January & 24.5 & 19.0 & 16.0 & 9.5 & 0 & 0 & 8.0 & 11.5 & 7.0 & 0 \\
\hline February & 20.5 & 30.0 & 23.0 & 20.5 & 12.5 & 0 & 12.0 & 7.0 & 3.0 & 2.0 \\
\hline March & 41.0 & 54.0 & 53.5 & 38.5 & 29.5 & 8.0 & 27.0 & 10.0 & 32.0 & 8.5 \\
\hline April & 8.5 & 10.0 & 9.5 & 7.5 & 5.5 & 4.5 & 1.0 & 2.5 & 2.0 & 0 \\
\hline \multicolumn{11}{|l|}{1989} \\
\hline January & 21.0 & 21.0 & 20.0 & 35.5 & 16.5 & 22.5 & 27.0 & 15.7 & 7.5 & 1.5 \\
\hline February & 59.0 & 34.0 & 50.5 & 30.5 & 60.5 & 60.5 & 10.0 & 19.0 & 13.0 & 3.0 \\
\hline March & 47.0 & 52.5 & 30.5 & 60.5 & 40.0 & 33.0 & 25.5 & 19.5 & 11.0 & 16.5 \\
\hline April & 24.0 & 20.0 & 14.5 & 20.0 & 13.0 & 13.5 & 16.0 & 7.5 & 8.0 & 6.5 \\
\hline
\end{tabular}

drone brood were found to be fertile, with the exception of some cells which were invaded a number of times. There was no indication of frequent uncapping and removal of Varroa-infested drone larvae.

\section{Transfer experiments}

Eight-10 days after within-colony grafting of already invaded and hence reproductive Varroa females from capped drone into worker brood cells, $75 \%$ of these mites had disappeared (table II). Nevertheless, most of the artificially infested worker cells were found properly sealed and containing a pupa at the expected stage. Apparently, the bees had merely removed the parasites. Of approximately $25 \%$ of mites which were recovered live, only a few had laid eggs, which equals $3 \%$ of all the grafted Varroa females. In other words, approximately $90 \%$ of the transferred mites surviving in worker brood remained infertile. This is not very different from the $100 \%$ infertility observed in the Varroa females which had naturally invaded worker brood cells.

\section{DISCUSSION}

\section{Artificial infestation}

We cannot exclude the possibility that in our experiments the manipulations had some negative effect on the grafted Varroa females. With one exception, the few fertile mites laid only one egg, and no hatched nymphs were found. However, in Europe and also in Brazil, similar transfers did not result in increased removal, mortality or infertility of the mites (Rosenkranz, 1990a, b). Experiments are scheduled in which we will attempt to answer this question for $c e$ rana bees by within-colony transfer between drone cells using the technique described here, and also by sham-transfers and modified methods.

\section{Mite fertility}

Although in colonies of Apis cerana indica Varroa jacobsoni females were found to invade not only drone but also worker brood 
Table II. Survival and fertility of reproductive Varroa jacobsoni females grafted from sealed drone to worker brood cells within the same colonies of Apis cerana indica.

\begin{tabular}{|c|c|c|c|c|c|c|}
\hline & \multicolumn{2}{|c|}{ Transfer experiments } & \multicolumn{3}{|c|}{ Female mites } & \multirow{3}{*}{$\begin{array}{l}\text { Total } \\
\text { No of } \\
\text { eggs }\end{array}$} \\
\hline & \multirow[t]{2}{*}{ Date } & \multirow{2}{*}{$\begin{array}{l}\text { No of used } \\
\text { colonies }\end{array}$} & \multirow[t]{2}{*}{ Transferred } & \multicolumn{2}{|c|}{ Recovered } & \\
\hline & & & & Live & With eggs & \\
\hline \multicolumn{7}{|c|}{1988} \\
\hline & 10.1 & 2 & 15 & 5 & 2 & 2 \\
\hline & 15.1. & 2 & 16 & 4 & - & - \\
\hline & 20.1 & 3 & 25 & 7 & - & - \\
\hline & 25.1 & 2 & 20 & 6 & - & - \\
\hline & 30.1 & 1 & 12 & 4 & 1 & 1 \\
\hline & 10.2 & 1 & 15 & 4 & - & - \\
\hline & 15.2. & 1 & 10 & 2 & - & - \\
\hline & 20.2 & 2 & 20 & 6 & - & - \\
\hline & 25.2 & 2 & 15 & 6 & 1 & 1 \\
\hline & 28.2 . & 2 & 25 & 7 & 2 & 2 \\
\hline & 5.3. & 1 & 12 & 4 & - & - \\
\hline & 10.3 & 2 & 20 & 5 & - & - \\
\hline & 15.3. & 3 & 16 & 3 & - & - \\
\hline \multicolumn{7}{|c|}{1989} \\
\hline & 7.1 . & 2 & 20 & 4 & - & - \\
\hline & 10.1 & 3 & 24 & 3 & - & - \\
\hline & 15.1 & 2 & 16 & 4 & 1 & 2 \\
\hline & 20.1 & 1 & 12 & 2 & 1 & 1 \\
\hline & 25.1. & 1 & 15 & 4 & - & - \\
\hline & 30.1 & 2 & 20 & 5 & 2 & 2 \\
\hline & 5.2 & 1 & 10 & 2 & - & - \\
\hline & 10.2 . & 1 & 20 & 4 & 1 & 1 \\
\hline & 15.2. & 2 & 35 & 10 & 2 & 2 \\
\hline & 20.2 & 1 & 12 & 4 & - & - \\
\hline & 25.2. & 2 & 16 & 2 & - & - \\
\hline Total & 24 & 42 & 421 & 107 & 13 & 14 \\
\hline$\%$ & & & 100 & 25.4 & 3.1 & \\
\hline
\end{tabular}

cells, reproduction of the parasite was restricted to drone hosts. A significant seasonal dependence of the reproductive success in drone brood was described earlier (Tewarson, 1987). Therefore, all the transfer experiments were conducted during early springtime when virtually $100 \%$ of the Varroa females, once they had entered drone cells, could be expected to become fertile. However, these graftings did not re- sult in normal fertility of the mites surviving in experimentally-infected worker brood cells. Only about $10 \%$ of the transferred and surviving Varroa females laid an egg. Hence the pronounced infestation of drone brood in Apis cerana colonies is not the only reason for the lack of Varroa reproduction in worker brood. Whether the restricted parasitization of worker larvae is caused primarily by a high preference of 
drone hosts by the female mites invading brood cells prior to operculation (Tewarson, 1986), or whether it is a secondary effect depending on the behavior of the adult bees is as yet unknown and should be evaluated by an in vitro bioassay (Rosenkranz et al, 1984).

Host-dependent conditions evidently determine the striking differences in the mites' reproductive success in drone and worker brood. A similar infertility of Varroa females in $50-60 \%$ of the worker brood cells of Africanized Apis mellifera colonies was described in Brazil (Ritter and de Jong, 1984; Camazine, 1986; Rosenkranz et al, 1990; Moretto et al, 1991) and found to correspond with tolerance to varroatosis. A worker-specific influence on mite fertility was similarly observed in colonies of different races of Apis mellifera in South America (Ruttner et al, 1984; Engels et al, 1986; Rosenkranz, 1990a) and Europe (Sulimanovic et al, 1986). It must be concluded that a low percentage of ovipositing Varroa mites in worker brood cells is an important trait of honey bee colonies resistant to varroatosis. Apparently the titer of juvenile hormone in the hemolymph of the host larva (Rosenkranz et al, 1990) does not regulate the reproduction of the female parasite, as suggested earlier (Hänel and Koeniger, 1986).

Of course Varroa infertility in worker brood of Apis cerana could also depend on environmental conditions. For instance, the cappings of drone brood cells are naturally perforated (Hänel and Ruttner, 1985; Oka$\mathrm{da}, 1990)$ and may faciliate gaseous exchange and thereby influence relative humidity as well as $\mathrm{CO}_{2}$ partial pressure inside the sealed cell (Abbas and Engels, 1989; Chiesa et al, 1989). However, in Apis mellifera the Varroa mites are fertile in worker and drone brood cells without cappings. Local comb temperature (Le Conte and Arnold, 1989) may also play a role since in the free-built cerana combs drone cells are always around the lower margin. Data on the exact temperature regime in the nest of Apis cerana are still lacking.

\section{Hygienic behavior}

The disappearance of artificially-introduced mites from sealed worker brood cells was also recently recorded by Rath and Drescher (1990) working with Apis cerana in Thailand. The cells are probably opened by the bees, and the Varroa females are removed or leave on their own accord. Thereafter the bees may seal the brood cells again, and the worker larvae develop normally. We did not observe the bees doing this, but the fact that 8-10 days later many cells did contain pupae of the expected age but no mites requires interpretation. Of course, direct visual control of the involved behavior of the broodattending adult worker bees by means of an observation hive is desirable. In contrast to our results, in Thailand nearly all worker cells into which live or dead mites had been placed were uncapped, and the mites and the bee larvae / pupae were always removed. In a few experiments with dead mites these bodies were taken out and the brood was sealed again as in our graftings. The differences are probably due to olfactory detection of the introduced mites by the cerana workers in Thailand since all the Varroa femaies had been collected from $A$ mellifera colonies. We had observed in preliminary experiments that mites sampled in other colonies, in particular of $A$ mellifera, were rapidly recognized and removed by $A c$ indica worker bees after artificial infestation. For that reason, we carried out all subsequent experimental mite introductions into capped worker brood cells as within-colony grafts. Nevertheless, about $75 \%$ of our transferred 
mites were not recovered. The removal of Varroa in response to their artifical introduction to worker brood was likewise observed in $A$ mellifera colonies (Boecking and Drescher, 1991). Again, mites from other colonies and, in addition, plastic combs were used which might have influenced the hygienic behavior of the workers. In the latter experiments, several removed mites were found injured and had evidently been killed by the mellifera workers. We assume that cerana bees treat removed mites in the same manner.

\section{Varroatosis resistance and mite reproduction}

The resistance mechanisms to varroatosis related to reproduction known up to now in the original as well as the secondary host species of honey bees obviously include various factors. In Apis cerana it has been observed that adult workers rapidly remove ectoparasitic mites by grooming and hence prevent the invasion of brood cells (Peng et al, 1987); however, these Varroa females had also been collected from Apis mellifera bees and this possibly explains why they were readily attacked. An extremely short duration of the post-capping phase of worker brood was determined in Apis mellifera capensis (Moritz and Hänel, 1984; Moritz and Mautz, 1990) and less pronounced in other African (Moritz, 1985) compared to European races (Le Conte and Cornuet, 1989; Büchler and Drescher, 1990; Schousboe, 1990). As a consequence, fewer female Varroa nymphs reach the adult stage. Attractivity of Apis mellifera worker larvae to invading Varroa females was found to be different according to the origin of the brood (Büchler, 1990). As confirmed by our studies, the differential hygienic behavior of Apis cerana workers results in rather more mites re- moved from infested worker than from drone brood (Koeniger, 1987; Rath and Drescher, 1990). Varroa infertility in worker brood is undoubtedly another important factor of resistance towards varroatosis in this species (de Jong, 1988) and was likewise observed in the Africanized Apis mellifera from Brazil (Ritter and de Jong, 1984; Camazine, 1986; Rosenkranz et al, 1990). The consequence of this extremely low rate of reproduction is evident and not comparable to some seasonal variation in reproductive success, as reported for Varroa populations in Europe (Blum, 1989; Otten and Fuchs, 1990). The reasons for such reproductive limitations still remain unknown. Meanwhile, the various data available on host-parasite relationships between eastern as well as western honey bees and Varroa jacobsoni point to a complex of factors which are responsible for any tolerance towards parasitization by this mite. In particular, any inhibition of its reproduction (Rosenkranz, 1990a) plays a decisive role in the population dynamics of the parasite. This important aspect has to be considered more distinctly in breeding programs (Büchler, 1989) designed to select strains of European honey bees tolerant to varroatosis.

Résumé - Reproduction de Varroa jacobsoni dans des colonies d'Apis cerana indica en conditions naturelles et en conditions artificielles. Dans 10 colonies d'Apis cerana indica à Allahabad (Inde), on a contrôlé le parasitisme naturel du couvain par Varroa jacobsoni en inspectant 2 fois par mois 100 cellules de couvain operculé d'ouvrières, et 100 de mâles lorsqu'il y en avait. Au printemps il n'y avait presque pas d'acariens sur le couvain d'ouvrières; pendant la saison des pluies par contre et dans certaines colonies, plus de $5 \%$ des cellules d'ouvrières renfermaient des varroas femelles. Pourtant celles-ci ne se reproduisaient pas. Sur le couvain de máles, 
au contraire, tous les acariens étaient fertiles. Le taux d'infestation du couvain de mâles de janvier à avril 1988 et 1989 a fortement varié d'une colonie à l'autre et d'une année à lautre et atteint $60 \%$ dans certaines colonies (tableau I), la moyenne étant de $34 \%$ (fig 1). En conséquence c'est le printemps, de janvier à avril à Allahabad, qui a été choisi pour les essais. En transférant les acariens des cellules récemment operculées de mâles dans des cellules récemment operculées d'ouvrières, on a voulu tester si les femelles de Varroa réellement reproductrices réussissaient à pondre après le transfert.

Au cours de 2 périodes, on a ainsi transféré plus de 400 varroas femelles. Lors d'essais préliminaires on avait observé que des varroas, rassemblés pour une infestation artificielle dans d'autres colonies, avaient été éliminés sur-le-champ après transfert dans les cellules operculées d'ouvrières. Cela se produisait en particulier lorsque les acariens provenaient de colonies d'Apis mellifera. Aussi, dans toutes les autres expériences, n'avons nous transféré des varroas femelles qu'au sein d'une même colonie d'A $c$ indica. Huit à dix jours plus tard, les acariens avaient disparu de $75 \%$ des cellules d'ouvrières infestées artificiellement. Les cellules étaient pourtant en majorité operculées et renfermaient une nymphe d'abeille. De toute évidence, les abeilles les avaient réoperculées. Nous n'avons malheureusement pas pu observer si les varroas étaient éliminés, et peut-être tués, par les abeilles ou si celles-ci ne contrôlaient et n'ouvraient que les cellules manipulées par nous et laissaient les varroas s'en échapper. Sur les 100 varroas retrouvés, $12 \%$ seulement, soit $3 \%$ du nombre total de femelles transplantées, avaient pondu (tableau II). Aucune nymphe éclose n'a été trouvée.

Nous discutons de la signification de cette infertilité des varroas femelles sur le couvain d'ouvrières en termes de facteurs de résistance. Elle existe également, dans une moindre mesure, dans les colonies d' $A$ mellifera africanisées tolérantes à la varroatose. $\mathrm{Si}$, dans nos expériences, $1 / 4$ des cellules d'ouvrières infestées artificiellement n'a pas été nettoyé, cela peut être dû au fait que des varroas femelles ont été prélevés et utilisés au sein de la même colonie d'A $c$ indica. Par contre dans les expériences réalisées par Rath et Drescher (1990), les acariens, prélevés dans des colonies d'A mellifera, ont été reconnus à l'odeur par les abeilles $A c$ indica et donc éliminés presque totalement. Les facteurs de résistance connus liés à la reproduction des varroas prouvent que tout un ensemble de facteurs est responsable de la tolérance à la varroatose. Les causes n'ont été qu'insuffisamment étudiées. Nous pensons que, parmi celles-ci, un rôle décisif revient à l'infertilité des varroas femelles liée à l'hôte. Une plus grande importance doit être accordée à ce facteur dans les futurs programmes destinés à sélectionner des lignées d'A mellifera résistantes à Varroa.

Apis cerana / Varroa jacobsoni / reproduction / infertilité / résistance á la varroatose

\section{Zusammenfassung - Fortpflanzung} von Varroa jacobsoni in Völkern von Apis cerana indica unter natürlichen und experimentellen Bedingungen. Bei zehn Völkern von Apis cerana indica wurde in Allahabad, Indien, der natürliche Befall der Brut durch Varroa jacobsonikontrolliert, indem zweimal pro Monat je 100 verdeckelte Arbeiterinnen- und, falls vorhanden, Drohnenzellen untersucht wurden. Während des Frühjahrs wurden in der Arbeiterinnenbrut fast keine Milben gefunden, während der sommerlichen Regenzeit enthielten dagegen in einigen Völkern über $5 \%$ der Arbeiterinnenzellen 
Varroa-Weibchen. Diese pflanzten sich jedoch nicht fort. In Drohnenbrut waren dagegen alle Milben fertil. Der Infektionsgrad der Drohnenbrut lag in den Monaten Januar-April 1988 und 1989 in einzelnen Völkern bei bis zu 60\% (Tabelle I), wobei von Volk zu Volk und in den beiden Jahren erhebliche Schwankungen festgestellt wurden. Die Mittelwerte des Drohnenbrutbefalls erreichten $34 \%$ (Abb 1). Das zeitige Frühjahr, in Allahabad Januar-April, wurde daher für Versuche gewählt, bei denen durch Umsetzen von Milben zwischen verdeckelten Drohnen- und Arbeiterinnenzellen geprüft werden sollte, ob reproduktionsaktive Varroa-Weibchen zur Eiablage gelangen, wenn sie in Arbeiterinnenbrut gebracht werden. Innerhalb von zwei Versuchsperioden wurden über 400 VarroaWeibchen aus kürzlich verdeckelten Drohnenzellen in ebensolche Arbeiterinnenzellen umgesetzt. In Vorversuchen hatten wir beobachtet, daß Milben, die für eine künstliche Infektion in anderen Völkern gesammelt worden waren, nach Einsetzen in verdeckelte Arbeiterinnenbrut alsbald ausgeräumt wurden. Dies erfolgte insbesondere dann, wenn die Milben aus Apis melliferaVölkern stammten. In allen weiteren Versuchen haben wir daher die VarroaWeibchen stets innerhalb desselben Apis cerana indica-Volkes umgesetzt. Acht bis zehn Tage später waren aus ca 300 der künstlich infizierten Arbeiterinnenzellen trotzdem die Milben verschwunden. Die Mehrzahl dieser Zellen wurde jedoch verdeckelt vorgefunden und enthielt eine Bienenpuppe. Offensichtlich hatten die Bienen die Zellen wieder verschlossen. Leider konnten wir nicht beobachten, ob die Milben gezielt ausgeräumt und vielleicht von den Bienen getötet wurden, oder ob diese nur die von uns manipulierten Zellen kontrollierten, öffneten und dabei eventuell die Milben entweichen ließen. Von den über 100 wiedergefundenen Milben hatten nur $12 \%$, was $3 \%$ der insgesamt umge- setzten Varroa-Weibchen entspricht, Eier abgelegt (Tabelle II). Geschlüpfte Nymphen fanden wir nicht. Die Bedeutung dieser Unfruchtbarkeit von VarroaWeibchen in Arbeiterinnenbrut als Resistenzfaktor wird diskutiert. Sie ist in schwächerem Maße auch bei den ebenfalls Varroatose-toleranten afrikanisierten Apis mellifera-Völkern in Brasilien ausgeprägt. Daß in unseren Versuchen rund 1/4 der künstlich infizierten Arbeiterinnen-Brutzellen nicht ausgeräumt wurde, könnte darauf beruhen, daß hierfür erstmals nur innerhalb derselben Apis cerana-Völker gesammelte Varroa-Weibchen verwendet wurden. Hingegen sind bei ähnlichen Experimenten anderer Autoren (Rath und Drescher, 1990) durchweg aus Apis mellifera-Völkern gewonnene Milben eingesetzt worden, die möglicherweise von den Apis ceranaBienen am Geruch erkannt und deswegen fast gänzlich eliminiert wurden. Die bis jetzt in Zusammenhang mit der MilbenFortpflanzung bekannt gewordenen Resistenzfaktoren weisen darauf hin, daß eine Varroatose-Toleranz offensichtlich durch einen Komplex verschiedener Faktoren bedingt ist. Deren Ursachengefüge ist erst unzureichend erforscht worden. Wir meinen, daß dabei einer wirtsbedingten Unfruchtbarkeit der Milbenweibchen eine entscheidende Bedeutung zukommt. In künftigen Arbeitsprogrammen für eine Auslese Varroatose-resistenter Linien von Apis mellifera sollte diesem Faktor größere Bedeutung beigemessen werden.

\section{Apis cerana / Varroa jacobsoni / Repro- duktion / Infertilität / Varroatose- Resistenz}

\section{REFERENCES}

Abbas ND, Engels W (1989) Rearing of Varroa in artificial cells on drones. In: Present Status of Varroatosis in Europe and Progress in the 
Varroa Mite Control (Cavalloro R, ed) EC Publ, Luxembourg, 223-228

Blum R (1989) Reprodukion der Varroa-Milbe bei unterschiedlicher Protein-Versorgung der Bienenvölker. Apidologie 20, 509-512

Boecking O, Drescher W (1991) Response of Apis mellifera $\mathrm{L}$ colonies infested with Varroa jacobsoni Oud. Apidologie 22, 237-241

Büchler R (1989) Auslese und Zucht varroaresistenter Bienen. Bericht aus dem laufenden Forschungsprojekt. Allg Dtsch Imkerztg 23, 194-198

Büchler R (1990) Möglichkeiten zur Selektion auf erhöhte Varroa-Toleranz mitteleuropäischer Bienenherkünfte. Apidologie 21, 365-367

Büchler R, Drescher W (1990) Variance and heritability of the capped developmental stage in European Apis mellifera $L$ and its correlation with increased Varroa jacobsoni Oud infestation. J Apic Res 29, 172-176

Camazine $S$ (1986) Differential reproduction of the mite, Varroa jacobsoni (Mesostigmata: Varroidae) on Africanized and European honeybees. Ann Entomol Soc Am 79, 801 803

Chiesa F, Milani N, D'Agaro M (1989) Observations on the reproductive behaviour of Varroa jacobsoni Oud: technique and preliminary results. in: Present Status of Varroatosis in Europe and Progress in the Varroa Mite Control (Cavalloro R, ed) EC Publ, Luxembourg, 213-222

Engels W, Rosenkranz P, Hertl F, Staemmler G (1984) Biologische Varroa-Kontrolle durch Drohnenbrutentnahme. Apidologie 15, 246248

Engels W, Gonçalves LS, Steiner J, Buriolla AM, Cavichio Issa MR (1986) Varroa-Befall von Carnica-Völkern in Tropenklima. Apidologie 17, 203-216

Fuchs S (1990) Preference for drone brood cells by Varroa jacobsoni Oud in colonies of Apis mellifera carnica. Apidologie 21, 193199

Hänel $H$, Ruttner $F$ (1985) The origin of the pore in the drone cell capping of Apis cerana Fabr. Apidologie 16, 157-164

Hänel $\mathrm{H}$, Koeniger $\mathrm{N}$ (1986) Possible regulation of the reproduction of the honey bee mite
Varroa jacobsoni (Mesostigmata: Acari) by a host's hormone: juvenile hormone III. J Insect Physiol 32, 791-798

Issa MRC, Gonçalves LS (1984) Study of preference of the acarid Varroa jacobsoni for drones of Africanized honeybees. Adv Invertebr Reprod 3, 598

de Jong $D$ (1988) Varroa jacobsoni does reproduce in worker cells of Apis cerana in South Korea. Apidologie 19, 241-244

Koeniger N (1987) Die östliche Honigbiene und ihre Milbe Varroa jacobsoni. Imkerfreund 42, 303-306

Koeniger $\mathrm{N}$, Koeniger $\mathrm{G}$, Wijayagunasekara $\mathrm{N}$ (1981) Beobachtungen über die Anpassung von Varroa jacobsoni an ihren natürlichen Wirt Apis cerana in Sri Lanka. Apidologie 12, 37-40

Koeniger $\mathrm{N}$, Koeniger $\mathrm{G}$, Delfinado-Baker $\mathrm{M}$ (1983) Observations on mites of the Asian honeybee species. Apidologie 14, 197-204

Le Conte Y, Arnold G (1989) Effects of the brood temperature on the development of Varroa jacobsoni. In: Present Status of Varroatosis in Europe and Progress in the Varroa Mite Control (Cavalloro R, ed) EC Publ, Luxembourg, 93-95

Le Conte Y, Cornuet ZM (1989) Variability of the post-capping stage duration of the worker brood in three different races of Apis mellifera. In: Present Status of Varroatosis in Europe and Progress in the Varroa Mite Control (Cavalloro R, ed), EC Publ, Luxembourg, 171-174

Moretto G, Gonçalves LS, de Jong D, Bichuette MZ (1991) The effects of climate and bee race on Varroa jacobsoni Oud infestations in Brazil. Apidologie 22, 197-203

Moritz RFA (1985) Heritability of the postcapping stage in Apis mellifera and its relation to varroatosis resistance. $J$ Hered 76, 267-270

Moritz RFA, Hänel H (1984) Restricted development of the parasitic mite Varroa jacobsoni Oud in the Cape honeybee Apis mellifera capensis Esch. $Z$ Angew Entomol 97, 91-95

Moritz RFA, Mautz D (1990) Development of Varroa jacobsoni in colonies of Apis mellifera capensis and Apis mellifera carnica. Apidologie 21, 53-58

Okada I (1990) A Book on the Japanese Honeybee. Tamagawa Univ Press, Tokyo 
Otten C, Fuchs S (1990) Saisonale Unterschiede im Reproduktionsverhalten von Varroa jacobsoni in Völkern der Rassen $A$ mellifera carnica, $A m$ ligustica und $A m$ mellifera. Apidologie 21, 367-368

Peng YS, Fang Y, Xu S, Ge L (1987) The resistance mechanism of the Asian honeybee, Apis cerana Fabr, to an ectoparasitic mite, Varroa jacobsoni Oudemans. $J$ Invertebr Pathol 49, 54-60

Rath W, Drescher W (1990) Response of Apis cerana Fabr towards brood infested with Varroa jacobsoni Oud an infestation rate of colonies in Thailand. Apidologie 21, 311-321

Ritter W, de Jong D (1984) Reproduction of Varroa jacobsoni Oud in Europe, the Middle East and tropical South America. $Z$ Angew Entomol 98, 55-57

Rosenkranz P (1990a) Der Einfluß larvaler Bienenhämolymphe auf die Fertilität von Varroa jacobsoni in europäischen und afrikanisierten Bienenvölkern. Apidologie 21, 370-372

Rosenkranz P (1990b) Wirtsfaktoren in der Steuerung der Reproduktion der parasitischen Bienenmilbe Varroa jacobsoni in Völkern von Apis mellifera. Dissertation, Universität Tübingen

Rosenkranz P, Engels W (1985) Konsequente Drohnenbrut-Entnahme, eine wirksame Maßnahme zur Minderung von VarroatoseSchäden in Bienenvölkern. Allg Dtsch $\mathrm{Im}$ kerztg 19, 265-271

Rosenkranz P, Tewarson NC, Engels W (1984) Optimal host selection by reproductive Varroa jacobsoni. Adv Invertebr Reprod 3, 628
Rosenkranz P, Rachinsky A, Strambi A, Strambi C, Röpstorf P (1990) Juvenile hormone titer in capped worker brood of Apis mellifera and reproduction in the bee mite Varroa jacobsoni. Gen Comp Endocrinol 78, 189-193

Ruttner F, Marx H, Marx G (1984) Beobachtungen über eine mögliche Anpassung von Varroa jacobsoni an Apis mellifera $L$ in Uruguay. Apidologie 15, 43-62

Schousboe C (1990) Seasonal variation in duration of capped stage in worker bee brood Apis mellifera L. Tidsskr Biav/ 124, 50-52

Schulz AE (1984) Reproduktion und Populationsentwicklung der parasitischen Milbe Varroa jacobsoni Oud in Abhängigkeit von Brutzyklus ihres Wirtes Apis mellifera L. Apidologie 15, 401-420

Sulimanovic D, Ruttner F, Pechhacker H (1982) Studies on the biology of reproduction of Varroa jacobsoni. Honeybee Sci 3, 109-112 (in Japanese)

Sulimanovic D, Ruttner F, Spitzer M, Pechhacker H (1986) Reduced fertility of Varroa jacobsoni on worker brood. Int Varroa Workshop, Feldafing

Tewarson NC (1986) Reproductive strategies in Varroa jacobsoni, an ectoparasitic mite of honey bees. Adv Invertebr Reprod 4, 545

Tewarson NC (1987) Use of host hemolymph proteins, seasonal reproduction and a hypothesis on nutritional imprinting in the honey bee mite, Varroa jacobsoni, on Apis mellifera and Apis cerana. In: Chemistry and Biology of Social insects (Eder J, Rembold H, eds) Peperny, Munich, 688-689 